\author{
Maciej Tokarski \\ Wyższa Szkoła Bankowa \\ w Toruniu
}

\title{
Fundusze unijne szansą na rozpoczęcie działalności gospodarczej przez mikro-, małych i średnich przedsiębiorców
}

Celem europejskiej polityki regionalnej w latach 2007-2013 jest umocnienie solidarności Unii poprzez dążenie do spójności gospodarczej i społecznej, zmniejszające różnice w poziomie rozwoju poszczególnych regionów. Dzięki szczególnemu podejściu europejska polityka regionalna zapewnia działaniom prowadzonym w terenie „,wartość dodaną”. Pomaga ona sfinansować konkretne projekty na rzecz regionów, miast i ich mieszkańców. Ideą jest stworzenie warunków, by regiony mogły w pełni odegrać swoją rolę w dążeniu do rozwoju i konkurencyjności oraz mogły równocześnie wymieniać między sobą pomysłami i „dobrymi praktykami”. Całość polityki regionalnej uwzględnia priorytety określone przez Unię Europejską na rzecz wzrostu i zatrudnienia (Naruszewicz, s. 35).

Polsce na lata 2007-2013 przyznano ponad 85,6 mld euro unijnej pomocy na realizację różnych programów, mających na celu zmniejszenie dysproporcji w rozwoju naszego kraju względem pozostałych krajów członkowskich. W puli tych środków znajdują się również te, które są przeznaczone na rozpoczęcie działalności gospodarczej.

Celem tego artykułu jest zaprezentowanie funduszy unijnych przeznaczonych dla polskich przedsiębiorców z sektora MŚP na rozpoczęcie działalności gospodarczej w latach 2007-2013 oraz ukazanie barier w dostępie do środków unijnych.

\section{Ramy prawne regulujące przekazywanie funduszy unijnych w latach 2007-2013}

Polsce na lata 2007-2013 przyznano ponad 85,6 mld euro unijnej pomocy, w tym 67,3 mld euro będzie pochodziło z budżetu UE, 11,9 mld euro z krajowych środków publicznych (w tym ok. 5,93 mld euro z budżetu państwa), a ok. 6,4 mld euro zostanie zaangażowanych ze strony podmiotów prywatnych. Jest to blisko $1 / 5$ ogólnej sumy środków przeznaczonych na politykę spójności Unii Europejskiej w latach 2007-2013. Polska jest największym beneficjentem środków pomocowych w grupie nowych państw członkowskich Unii, a wsparcie przedsiębiorców udzielane będzie w ramach programów operacyjnych, przy czym szczegółowy podział funduszy strukturalnych i Funduszu Spójności w Polsce w układzie poszczególnych programów operacyjnych kształtuje się w następujący sposób:

Program Infrastruktura i Środowisko - 41,9\% całości środków (27,9 mld euro),

- 16 programów regionalnych - 24,9\% całości środków (16,6 mld euro),

- Program Kapitał Ludzki - 14,6\% całości środków (9,7 mld euro),

- Program Innowacyjna Gospodarka - 12,4\% całości środków (8,3 mld euro),

- Program Rozwój Polski Wschodniej - 3,4\% całości środków (2,3 mld euro),

- Program Pomoc Techniczna - 0,8\% całości środków (0,5 mld euro),

- Programy Europejskiej Współpracy Terytorialnej (0,7 mld euro),

- Pozostałe środki finansowe w ramach obu funduszy strukturalnych oraz Funduszu Spójności zostaną przeznaczone na utworzenie krajowej rezerwy wykonania (2\% wartości alokacji, czyli 1,3 mld euro). 
Już z nazw poszczególnych programów można wstępnie zorientować się, czego programy te dotyczą. Generalne założenie jest takie, że każdy program określa konkretne cele, sposoby ich realizacji (czyli możliwe do sfinansowania działania i koszty), adresatów (czyli odbiorców działań) oraz realizatorów (czyli stwierdza, jaka instytucja czy organizacja może ubiegać się o finansowanie) (Jankowska, Kierkowski, Knopik 2004, s. 11). Ponadto zasadniczą zmianą w perspektywie finansowej 2007-2013 jest włączenie środków unijnych do budżetu państwa po stronie dochodów budżetowych.

Dokumentem określającym kierunki i wysokość wsparcia finansowego ze strony funduszy na realizację zamierzeń rozwojowych w Polsce w latach 2007-2013 jest Narodowa Strategia Spójności (NSS, nazwa urzędowa: Narodowe Strategiczne Ramy Odniesienia). Narodowa Strategia Spójności to dokument strategiczny określający priorytety i obszary wykorzystania oraz system wdrażania Europejskiego Funduszu Rozwoju Regionalnego, Europejskiego Funduszu Społecznego oraz Funduszu Spójności w Polsce w ramach budżetu Wspólnoty na lata 2007-2013. Zgodnie z NSS, celem strategicznym jest tworzenie warunków dla wzrostu konkurencyjności gospodarki polskiej opartej na wiedzy i przedsiębiorczości, zapewniającej wzrost zatrudnienia oraz wzrost poziomu spójności społecznej, gospodarczej i przestrzennej. Cel strategiczny osiagany będzie poprzez realizację horyzontalnych celów szczegółowych. Celami horyzontalnymi przyjętymi w NSS są:

1. poprawa jakości funkcjonowania instytucji publicznych oraz rozbudowa mechanizmów partnerstwa,

2. poprawa jakości kapitału ludzkiego i zwiększenie spójności społecznej,

3. budowa i modernizacja infrastruktury technicznej oraz społecznej mającej podstawowe znaczenie dla wzrostu konkurencyjności Polski,

4. podniesienie konkurencyjności i innowacyjności przedsiębiorstw, w tym szczególnie sektora wytwórczego o wysokiej wartości dodanej oraz rozwój sektora usług,

5. wzrost konkurencyjności polskich regionów i przeciwdziałanie ich marginalizacji społecznej, gospodarczej i przestrzennej,

6. wyrównywanie szans rozwojowych i wspomaganie zmian strukturalnych na obszarach wiejskich.

Obok działań o charakterze prawnym, fiskalnym i instytucjonalnym, cele NSS będą realizowane za pomocą tzw. programów operacyjnych, zarządzanych przez Ministerstwo Rozwoju Regionalnego, tzw. regionalnych programów operacyjnych, zarządzanych przez zarządy poszczególnych województw i projektów współfinansowanych ze strony instrumentów strukturalnych, tj.:

- Program Infrastruktura i Środowisko - EFRR i FS,

- Program Innowacyjna Gospodarka - EFRR,

- Program Kapitał Ludzki - EFS,

- 16 programów regionalnych - EFRR,

- Program Rozwój Polski Wschodniej - EFRR,

- Program Pomoc Techniczna - EFRR,

- Programy Europejskiej Współpracy Terytorialnej - EFRR.

Możliwość wykorzystania środków unijnych osadzona została w świetle obowiązujących

przepisów prawnych zarówno krajowych, jak i unijnych, do których należą:

- Narodowa Strategia Spójności - przyjęta w drodze uchwały Rady Ministrów z dnia 29 listopada 2006 r.,

- Rozporzqdzenie Rady (WE) nr 1083/2006 z dnia 11 lipca 2006 r. ustanawiajace przepisy ogólne dotyczace EFRR, EFS oraz Funduszu Spójności i uchylajace rozporzadzenie (WE) nr 1260/1999, 
- Rozporzadzenie (WE) nr 1080/2006 Parlamentu Europejskiego i Rady z dnia 5 lipca 2006 r. w sprawie Europejskiego Funduszu Rozwoju Regionalnego i uchylajace rozporzadzenie (WE) $n r 1783 / 1999$,

- Rozporzqdzenie (WE) nr 1081/2006 Parlamentu Europejskiego i Rady z dnia 5 lipca 2006 $r$. w sprawie Europejskiego Funduszu Społecznego i uchylajace rozporzadzenie (WE) nr 1784/1999,

- Rozporzqdzenie Rady (WE) nr 1084/2006 z dnia 11 lipca 2006 r. ustanawiajace Fundusz Spójności i uchylajace rozporzadzenie (WE) nr 1164/94,

- Rozporzqdzenie (WE) nr 1082/2006 Parlamentu Europejskiego i Rady z dnia 5 lipca 2006 r. w sprawie europejskiego ugrupowania wspótpracy terytorialnej,

- Rozporzadzenie Komisji (WE) nr 1828/2006 z dnia 8 grudnia 2006 r. ustanawiajace szczegółowe zasady wykonania rozporzadzenia Rady (WE) nr 1083/2006 ustanawiajacego przepisy ogólne dotyczqce Europejskiego Funduszu Rozwoju Regionalnego, Europejskiego Funduszu Społecznego oraz Funduszu Spójności oraz rozporzqdzenia (WE) nr 1080/2006 Parlamentu Europejskiego i Rady w sprawie Europejskiego Funduszu Rozwoju Regionalnego.

Analizując krajowe akty prawne pod kątem wdrażania środków unijnych, można zidentyfikować wiele przepisów regulujących prawa i obowiązki podmiotów korzystających z funduszy strukturalnych lub Funduszu Spójności. Podstawowym aktem prawa krajowego regulującym ogólne zasady wykorzystania środków pochodzących z budżetu UE w okresie programowania 2007-2013 jest Ustawa z dnia 6 grudnia 2006 r. o zasadach prowadzenia polityki rozwoju (DzU 2006, nr 227, poz. 1658 z późn. zm.).

Ponadto do krajowych aktów prawnych, kluczowych w kontekście wdrażania środków unijnych, należą:

- Ustawa z dnia 7 listopada 2008 r. o zmianie niektórych ustaw w zwiazku z wdrażaniem funduszy strukturalnych i Funduszu Spójności (DzU 2008, nr 216 poz. 1370),

- Ustawa z dnia 8 grudnia 2006 r. o zmianie ustawy o finansach publicznych oraz niektórych innych ustaw (DzU 2006, nr 249, poz. 1832),

- Ustawa z dnia 30 czerwca 2005 r. o finansach publicznych (DzU 2005, nr 249, poz. 2104 z późn. zm.),

- Obwieszczenie Marszatka Sejmu Rzeczypospolitej Polskiej z dnia 20 listopada 2007 r. w sprawie ogłoszenia jednolitego tekstu ustawy - Prawo zamówień publicznych (DzU 2007, nr 223, poz. 1655),

- Ustawa z dnia 29 września 1994 r. o rachunkowości późn. zmianami (DzU 2009, nr 152, poz. 1223, nr 157, poz. 1241),

- Rozporzqdzenie Ministra Rozwoju Regionalnego z dnia 7 września 2007 r. w sprawie wydatków zwiqzanych z realizacja programów operacyjnych.

\section{Fundusze unijne na rozpoczęcie działalności gospodarczej w latach 2007-2013}

W latach 2007-2013 przewidziano 4 programy kontynuujące ideę przedsiębiorczości:

1. Program Operacyjny Innowacyjna Gospodarka (PO IG) - Działanie 3.1. Inicjowanie działalności innowacyjnej;

2. Program Operacyjny Kapitał Ludzki (PO KL) - Działanie 6.2. Wsparcie oraz promocja przedsiębiorczości oraz samozatrudnienia;

3. Regionalne Programy Operacyjne (RPO) - działania osi priorytetowej nr 1 lub 2 w zależności od województwa;

4. Program Rozwoju Obszarów Wiejskich (PROW): 
- Działanie 3.1. Różnicowanie w kierunku działalności nierolniczej,

- Działanie 3.2. Tworzenie i rozwój mikroprzedsiębiorstw.

Wszystkie 4 wymienione powyżej programy mają na celu pomoc osobom, które chcą założyć lub rozwinąć własną działalność gospodarcza, przy czym każdy z nich adresowany jest do innego kręgu odbiorców.

\section{Dla osób, które mają ciekawe pomysły na biznes i szukają kapitału o znacznej wyso- kości przewidziane jest Działanie 3.1. Inicjowanie działalności innowacyjnej w ramach Programu Operacyjnego Innowacyjna Gospodarka.}

Program Innowacyjna Gospodarka to jeden z 6 programów krajowych Narodowych Strategicznych Ram Odniesienia, który finansowany jest ze środków europejskich. Jest to program skierowany przede wszystkim do przedsiębiorców, którzy zamierzają realizować innowacyjne projekty związane z badaniami i rozwojem, nowoczesnymi technologiami, inwestycjami o dużym znaczeniu dla gospodarki lub wdrażaniem i stosowaniem technologii informacyjnych i komunikacyjnych.

W latach 2007-2013 w ramach tego programu przedsiębiorcy, instytucje otoczenia biznesu, jednostki badawcze i naukowe oraz instytucje administracji publicznej uzyskają wsparcie w wysokości przekraczającej 9,71 miliarda euro na realizację różnego rodzaju projektów, które przyczynią się do podniesienia innowacyjności polskiej gospodarki i polskich przedsiębiorstw. Z kwoty tej 8,25 miliarda euro stanowią środki z Europejskiego Funduszu Rozwoju Regionalnego (EFRR), a pozostałe 1,46 miliarda euro pochodzi z budżetu krajowego. W ramach programu wspierane będą działania z zakresu innowacyjności produktowej, procesowej, marketingowej i organizacyjnej, które w sposób bezpośredni lub pośredni przyczyniają się do powstawania i rozwoju innowacyjnych przedsiębiorstw. Program ma na celu wspieranie szeroko rozumianej innowacyjności (w skali kraju lub na poziomie międzynarodowym). W ramach POIG wsparcie mogą otrzymać przedsiębiorstwa, instytucje otoczenia biznesu oraz jednostki naukowe, które chcą pomóc firmom we wdrażaniu najnowszych rozwiązań technologicznych. Ponadto POIG finansuje duże projekty, które mają na celu stworzenie odpowiednich warunków rozwoju dla innowacyjnych przedsiębiorstw. Ważne jest, aby firma, która chce pozyskać środki z POIG, chciała realizować projekt związany z innowacyjnością produktową (wytworzenie nowego, lepszego produktu), procesową (wytworzenie produktu w inny, nowocześniejszy sposób), marketingową lub organizacyjną. Należy pamiętać, że w ramach POIG nie będzie wspierana innowacyjność na poziomie lokalnym lub regionalnym. Tego rodzaju innowacyjne projekty (tzn. o zasięgu lokalnym i regionalnym) będą finansowane z Regionalnych Programów Operacyjnych i Programu Operacyjnego Rozwój Polski Wschodniej.

Celem głównym Programu Innowacyjna Gospodarka na lata 2007-2013 jest rozwój polskiej gospodarki w oparciu o innowacyjne przedsiębiorstwa. Fundusze w ramach programu zostały podzielone na tzw. osie priorytetowe, czyli priorytety, które pozwolą osiagnąć cel główny oraz cele szczegółowe. W programie określono dziewięć priorytetów, w tym osiem merytorycznych oraz priorytet Pomocy Technicznej, przy czym z punktu widzenia możliwości pozyskania wsparcia na rozpoczęcie działalności gospodarczej istotne jest zwrócenie uwagi na Oś priorytetową 3 - Kapital dla innowacji.

Celem osi priorytetowej 3 jest zwiększenie liczby przedsiębiorstw wykorzystujących innowacyjne rozwiązania oraz zwiększenie dostępu do zewnętrznych źródeł finansowania przedsięwzięć innowacyjnych. W ramach tej osi realizowane są następujące działania (w nawiasach podano instytucje pośredniczące i wdrążające): 


\section{1. inicjowanie działalności innowacyjnej (Ministerstwo Gospodarki/Polska Agencja Rozwo-} ju Przedsiębiorczości),

3.2. wspieranie funduszy kapitału podwyższonego ryzyka (Ministerstwo Gospodarki),

3.3. tworzenie systemu ułatwiającego inwestowanie w MŚP (Ministerstwo Gospodarki/Polska Agencja Rozwoju Przedsiębiorczości).

Działanie 3.1. obejmuje wsparcie w zakresie tworzenia na podstawie innowacyjnych pomysłów nowych przedsiębiorstw, w tym spin off'ów, poprzez doradztwo, udostępnienie infrastruktury i usług niezbędnych dla nowopowstałych przedsiębiorstw oraz zasilenia finansowego nowopowstałego przedsiębiorstwa. Celem działania jest więc zwiększenie liczby przedsiębiorstw, które opierają się na innowacyjnych rozwiązaniach. Wsparciem objęte będą projekty związane z poszukiwaniem i oceną innowacyjnych pomysłów potencjalnych przedsiębiorców, pracami przygotowawczymi mającymi na celu utworzenie nowego przedsiębiorstwa na bazie tego pomysłu oraz inwestycjami kapitałowymi w nowopowstałe przedsiębiorstwo. Instytucją wdrażającą jest Polska Agencja Rozwoju Przedsiębiorczości, a działanie skierowane jest głównie do nowopowstałych przedsiębiorców oraz instytucji wspierających powstawanie nowych firm innowacyjnych np. inkubatory przedsiębiorczości akademickiej, centra transferu technologii i innowacji, akceleratory technologii, parki naukowo-technologiczne.

Realizacja działania obejmuje wybór instytucji, które będą udzielały dwuetapowego wsparcia powstającym innowacyjnym przedsiębiorstwom. Instytucje te będą poszukiwać i dokonywać selekcji innowacyjnych pomysłów, pomagać w utworzeniu nowego przedsiębiorstwa (tzw. preinkubacja), a następnie inwestować w nowopowstałe przedsiębiorstwo. Dofinansowanie projektu składa się z dwóch komponentów: dotacji na preinkubację oraz zasilenia kapitałowego nowopowstałego przedsiębiorcy. Wejście kapitałowe następuje w sytuacji, gdy wyniki działań podjętych w zakresie preinkubacji wskażą na ekonomiczną zasadność prowadzenia przez nowopowstałe przedsiębiorstwo działalności gospodarczej opartej na innowacyjnym rozwiązaniu i zaistnieje prawdopodobieństwo osiagnięcia zysku przez nowopowstałe przedsiębiorstwo. Wejście kapitałowe może objąć wyłącznie podmioty, które przeszły etap preinkubacji (nie jest możliwy udział wyłącznie w drugim etapie wsparcia).

Środki uzyskane po zakończeniu inwestycji (tzw. wyjściu z inwestycji) trafiają do instytucji wspierającej powstawanie innowacyjnych przedsiębiorstw, z przeznaczeniem na kontynuację działalności o takim samym charakterze.

O dofinansowanie może ubiegać się podmiot działający na rzecz innowacyjności, który spełnia łącznie następujące warunki:

1. nie działa w celu osiagnięcia zysku lub przeznacza zysk na cele zgodne z zadaniami, na które udzielono wsparcia na inicjowanie działalności innowacyjnej;

2. posiada niezbędny potencjał finansowy, techniczny, kadrowy i organizacyjny oraz doświadczenie w zakresie świadczenia usług związanych $\mathrm{z}$ wdrażaniem wyników prac badawczo-rozwojowych oraz transferu technologii;

3. zapewnia świadczenie usług objętych wsparciem przez osoby posiadające niezbędne kwalifikacje i doświadczenie w zakresie analizy i komercjalizacji rozwiązań innowacyjnych, transferu technologii oraz dokonywania inwestycji w spółki sektora mikroprzedsiębiorców, małych lub średnich przedsiębiorców;

3a) zobowiąże się do:

a) nieodpłatnego przekazania spółce, w której podmiot ten objął akcje lub udziały w ramach wsparcia na inicjowanie działalności innowacyjnej lub

b) wniesienia aportem do spółki powstałej w wyniku preinkubacji, środków trwałych lub wartości niematerialnych i prawnych; 
4. zobowiąże się do:

a) wykorzystania, w okresie realizacji projektu objętego wsparciem, towarów, wartości niematerialnych i prawnych oraz usług zakupionych ze środków wsparcia wyłącznie w celach związanych z jego realizacją,

b) prowadzenia odrębnej ewidencji księgowej dla projektu objętego wsparciem na inicjowanie działalności innowacyjnej,

c) przeznaczenia wpływów pochodzących ze zbycia akcji lub udziałów w spółce nabytych uprzednio ze środków wsparcia oraz z udziału w zyskach tej spółki na dalsze inicjowanie działalności innowacyjnej zgodnie z umową o udzielenie wsparcia.

\section{W wypadku mniej skomplikowanych działalności gospodarczych warto zwrócić uwa- gę na Działanie 6.2. Wsparcie oraz promocja przedsiębiorczości oraz samozatrudnienia w ramach Programu Operacyjnego Kapitał Ludzki.}

W ostatnim czasie coraz więcej ludzi myśli o założeniu własnego biznesu. To typowe w czasie spowolnienia gospodarczego, kiedy firmy raczej zwalniają pracowników, niż przyjmują nowych. O własnej działalności poważnie myślą osoby, które nadal pracują, ci którzy któryś raz z rzędu u kolejnych pracodawców przeżyli finansowe rozczarowanie i bezrobotni. Wszyscy oni mogą ubiegać się o pieniądze unijne na rozpoczęcie działalności, a bezrobotni także o dotację z urzędu pracy. Warto pamiętać, że osoby bezrobotne nie mogą ubiegać się o pieniądze unijne z Programu Operacyjnego Kapitał Ludzki i w urzędzie pracy z Funduszu Pracy. Kwota pomocy unijnej jest wyższa niż z Funduszu Pracy. W ramach działania 6.2 z PO KL można otrzymać do 40000 zł, a z Funduszu Pracy maksymalnie do sześciu średnich płac.

Decyzję w sprawie przyjęcia do realizacji Programu Operacyjnego Kapitał Ludzki (PO KL) Komisja Europejska wydała dnia 28 września 2007 r. Jest to jeden z programów operacyjnych służących realizacji Narodowych Strategicznych Ram Odniesienia 2007-2013 i obejmuje całość interwencji Europejskiego Funduszu Społecznego (EFS) w Polsce. Program jest w całości realizowany ze środków Europejskiego Funduszu Społecznego. Celem strategicznym programu jest umożliwienie pełnego wykorzystania potencjału zasobów ludzkich, zarówno w wymiarze indywidualnym, jak i społecznym. W szczególności chodzi tu o koncentrację na obszarach zatrudnienia, edukacji, aktywizacji zawodowej, integracji społecznej oraz o budowę sprawnej administracji publicznej. Program Operacyjny Kapitał Ludzki ma na celu wzrost poziomu zatrudnienia i potencjału adaptacyjnego przedsiębiorstw i ich pracowników, podniesienie poziomu wykształcenia, zmniejszenie obszarów wykluczenia społecznego, wsparcie dla budowy struktur administracyjnych państwa oraz zwiększenie spójności społecznej i terytorialnej. Wszystkie działania realizowane w jego ramach mają wpływać na zwiększenie konkurencyjności gospodarki opartej na wiedzy i przedsiębiorczości. Wdrażanie wyżej wymienionych celów odbywać się będzie poprzez realizację projektów miękkich, takich jak szkolenia, seminaria, programy rozwojowe, doradztwo.

Program Operacyjny Kapitał Ludzki składa się z 10 priorytetów realizowanych na poziomie centralnym i regionalnym. W ramach komponentu centralnego środki zostaną przeznaczone przede wszystkim na wsparcie efektywności struktur i systemów instytucjonalnych, natomiast środki komponentu regionalnego zostaną w głównej mierze przeznaczone na wsparcie dla osób i grup społecznych.

Priorytety realizowane centralnie to:

- Priorytet I Zatrudnienie i integracja społeczna,

- Priorytet II Rozwój zasobów ludzkich i potencjału adaptacyjnego przedsiębiorstw oraz poprawa stanu zdrowia osób pracujących, 
- Priorytet III Wysoka jakość systemu oświaty,

- Priorytet IV Szkolnictwo wyższe i nauka,

- Priorytet V Dobre rządzenie, Priorytety realizowane na szczeblu regionalnym to:

- Priorytet VI Rynek pracy otwarty dla wszystkich,

- Priorytet VII Promocja integracji społecznej,

- Priorytet VIII Regionalne kadry gospodarki,

- Priorytet IX Rozwój wykształcenia i kompetencji w regionach.

Ponadto realizowany będzie Priorytet X Pomoc techniczna, którego celem jest zapewnienie właściwego zarządzania, wdrażania oraz promocji Europejskiego Funduszu Społecznego.

W ramach PO KL przewiduje się możliwość realizacji projektów w dwóch głównych trybach: systemowym i konkursowym. W trybie systemowym projekty są realizowane przez beneficjentów imiennie wskazanych w Programie lub dodatkowych dokumentach stanowiących jego uszczegółowienie. Natomiast $\mathrm{w}$ trybie konkursowym projekty będą mogły realizować wszystkie podmioty, m.in.:

- instytucje rynku pracy,

- instytucje szkoleniowe,

- jednostki administracji rządowej i samorządowej,

- przedsiębiorcy,

- instytucje otoczenia biznesu,

- organizacje pozarządowe,

- instytucje systemu oświaty i szkolnictwa wyższego,

- inne podmioty.

$\mathrm{Na}$ wsparcie przedsiębiorczości oraz samozatrudnienia przeznaczono środki w ramach priorytetu VI, działanie 6.2. Wsparcie oraz promocja przedsiębiorczości i samozatrudnienia. Działanie zostało skierowane do osób, które chcą rozpocząć własną działalność gospodarcza, pod warunkiem, że w okresie 1 roku przed przystąpieniem do projektu nie miały zarejestrowanej działalności gospodarczej. Dotacja nie będzie przysługiwała osobom, które już zarejestrowały działalność gospodarczą, ale jeszcze jej nie rozpoczęły. Wykluczeniu podlegają również osoby, które zawiesiły swoją działalność gospodarczą. Natomiast nie ma przeszkód w staraniu się o dotację przez osoby, które prowadziły działalność gospodarczą w okresie 1 roku przed przystapieniem do projektu poza granicami kraju.

Od osób starających się o dotację wymaga się spełnienia następujących dodatkowych warunków:

- nieposiadanie zaległości w zapłacie podatków oraz składek na ubezpieczenie społeczne,

- nietoczenia się przeciwko nim postępowania sądowego, administracyjnego, egzekucyjnego dotyczącego niespłaconych zobowiązań.

O dotację będą się mogły starać zarówno osoby bezrobotne, jak i pracujące. Wszystko jednak zależy od tego, jaką grupę docelową określiła instytucja realizująca projekt. Jeżeli projekt zakłada tylko udział osób zarejestrowanych jako bezrobotne, nie będą mogły w nim brać udziału osoby pracujące. Instytucja realizująca projekt może jednak uwzględnić rekrutację osób pracujących. Dotacje na uruchomienie działalności gospodarczej mają na celu wsparcie tej grupy osób, która znajduje się w trudnej sytuacji na rynku pracy.

Priorytetowo zostaną potraktowane projekty, które przewidują wsparcie dla:

- osób do 25 r. życia,

- osób niepełnosprawnych, 
- osób mieszkających w gminach wiejskich i miejsko-wiejskich oraz mieszkańców miast do 25 tys. zamierzających podjąć zatrudnienie w obszarach niezwiązanych z produkcją rolną i zwierzęca,

- osób pozostających bez zatrudnienia przez okres co najmniej 12 kolejnych miesięcy w ciągu ostatnich dwóch lat,

- kobiet, zwłaszcza powracających oraz wchodzących po raz pierwszy na rynek pracy po przerwie związanej z urodzeniem i wychowaniem dzieci,

- osób po 45 r. życia.

Maksymalna pomoc, jaką można otrzymać na ten cel, to kwota 40000 zł. Wysokość wsparcia jest przydzielana na podstawie potrzeb, które wykazane zostaną w ramach starania się o dotację. Oznacza to, że maksymalnie można uzyskać kwotę 40000 zł (lub do 20000 zł brutto na osobę w przypadku spółdzielni lub spółdzielni socjalnej), ale można też uzyskać dotację w kwocie niższej niż ww. W ramach starań o dotację na rozpoczęcie działalności gospodarczej nie zawsze należy posiadać wkład własny, ponieważ dotacja może być udzielana w formie zaliczki. Często jednak wypłata takiej dotacji na uruchomienie działalności gospodarczej następuje najpierw w formie zaliczki określonej procentowo od kwoty dofinansowania (np. 80\% z 20 tys., które stanowi całkowity koszt dotacji), a później refundacji własnych wydatków. Właśnie dlatego będą potrzebne własne środki, które zostaną nam zwrócone. Oprócz dotacji przewidziano inne formy wsparcia:

1. promocję związaną z kampaniami promocyjno-informacyjnymi oraz upowszechnianie dobrych praktyk,

2. doradztwo (indywidualne i grupowe) oraz szkolenia umożliwiające uzyskanie wiedzy i umiejętności potrzebnych do założenia i prowadzenia działalności gospodarczej,

3. wsparcie pomostowe $\mathrm{w}$ okresie od 6 do 12 miesięcy od dnia zarejestrowania działalności gospodarczej polegające na pomocy finansowej wypłacanej miesięcznie w kwocie nie większej niż 1100 zł brutto (spółdzielnia socjalna 550 zł brutto) obejmujące następujące rodzaje kosztów: daniny publicznoprawne, z wyjątkiem kar i grzywien, koszty opłat telekomunikacyjnych (telefon, internet itp.), wydatki na media (woda, gaz, elektryczność itp.), koszty dzierżawy, czynszu, najmu lokali, koszty najmu, dzierżawy maszyn i urządzeń, koszty ubezpieczeń majątkowych i osobistych, koszty zlecania usług związanych bezpośrednio z działalnością gospodarczą (np. zlecenie obsługi księgowej, prowadzenie strony internetowej itp.). Ponadto wsparcie pomostowe obejmuje dodatkowo również usługi doradczo-szkoleniowe o charakterze specjalistycznym.

Podmiotami odpowiedzialnymi za realizację działania 6.2. PO KL w każdym regionie są wojewódzkie urzędy pracy. Jednak to nie one przeprowadzają rekrutację na szkolenia oraz nie udzielają dotacji. Zadaniem WUP jest ogłoszenie konkursu właśnie w ramach wspomnianego działania 6.2., podczas którego swoje projekty maja złożyć instytucje zainteresowane przeprowadzaniem szkoleń oraz udzielaniem dotacji. To właśnie do tych instytucji, których projekty uznano za najlepsze, kierowane są osoby starające się o dotację na działalność gospodarczą, ponieważ to one przeprowadzą rekrutację ww. osób. Rekrutację przeprowadzają operatorzy. Mogą nim być różne instytucje, na przykład fundacje, stowarzyszenia. Lista operatorów w danym województwie znajduje się na stronach internetowych wojewódzkich urzędów pracy lub urzędów marszałkowskich. Operatorzy zamieszczają ogłoszenia w prasie i internecie. Osoby zainteresowane mogą pobrać formularz ze strony internetowej bądź w biurze projektu, a następnie wypełnić go i złożyć we wskazanym miejscu i terminie. Zawiera on informacje o potencjalnym wnioskodawcy oraz opis planowanego przedsięwzięcia. O tym, kto weźmie 
udział w projekcie, decyduje komisja rekrutacyjna. Ocenia ona najlepsze merytorycznie wnioski. Etapem kwalifikacji jest też rozmowa kwalifikacyjna. Już na etapie rekrutacji do projektu oceniany więc jest pomysł na biznes m.in. pod kątem realności, trwałości i innowacyjności. Oceniane też są predyspozycje psychologiczne do prowadzenia działalności gospodarczej, wykształcenie, doświadczenie zawodowe, dodatkowe kwalifikacje i umiejętności związane z profilem planowanej działalności.

Tab. 1. Podział środków na działanie 6.2. PO KL w poszczególnych województwach

\begin{tabular}{|l|c|c|c|}
\hline \multicolumn{1}{|c|}{ Województwo } & $\begin{array}{c}\text { Budżet } \\
\text { (mln euro) }\end{array}$ & $\begin{array}{c}\text { Udzial } \\
\text { w budżecie (\%) }\end{array}$ & $\begin{array}{c}\text { Wartość budżetu } \\
\text { na 1 mieszkańca }\end{array}$ \\
\hline Dolnośląskie & 27,4 & 6,73 & 9,20 \\
\hline Kujawsko-pomorskie & 22,6 & 5,55 & 10,76 \\
\hline Lubelskie & 28,9 & 7,10 & 12,93 \\
\hline Lubuskie & 10,1 & 2,48 & 9,87 \\
\hline Lódzkie & 28,5 & 7,00 & 10,74 \\
\hline Małopolskie & 33,3 & 8,18 & 10,33 \\
\hline Mazowieckie & 51,2 & 12,58 & 10,10 \\
\hline Opolskie & 9,8 & 2,42 & 9,00 \\
\hline Podkarpackie & 24,4 & 6,00 & 11,48 \\
\hline Podlaskie & 14,7 & 3,62 & 9,67 \\
\hline Pomorskie & 21,2 & 5,21 & 9,8 \\
\hline Śląskie & 47,7 & 11,72 & 13,53 \\
\hline Świętokrzyskie & 17,9 & 4,40 & 12,08 \\
\hline Warmińsko-mazurskie & 17,7 & 4,35 & 10,19 \\
\hline Wielkopolskie & 34,2 & 8,41 & 9,98 \\
\hline Zachodniopomorskie & 17,3 & 4,25 & $\mathrm{X}$ \\
\hline Razem & 406,9 & 100 & \\
\hline
\end{tabular}

Źródło: opracowanie własne.

Osoby zakwalifikowane do projektu biorą udział w bloku szkoleniowo-doradczym. Szkolenie dotyczy administracyjno-prawnych aspektów podejmowania i prowadzenia działalności gospodarczej, tworzenia biznesplanu itd. Trenerami są specjaliści, praktycy życia gospodarczego. Każdy uczestnik szkolenia może korzystać z doradztwa indywidualnego. Po zakończeniu szkolenia jego uczestnik składa wniosek o wsparcie finansowe. Ocenia go merytorycznie i formalnie komisja. Osoby, których wnioski zostały pozytywnie ocenione przez komisję, podpisują umowę o dofinansowanie. Dotacja jest bezzwrotna, pod warunkiem że przedsiębiorca będzie prowadził firmę przez minimum 12 miesięcy. Jeśli upadnie przed upływem roku, to będzie musiał zwrócić uzyskaną unijną pomoc. Dotację można przeznaczyć na pokrycie wydatków inwestycyjnych (w tym m.in. na środki transportu, składniki majątku trwałego, koszty prac remontowych i budowlanych) i na środki obrotowe, w szczególności na zakup surowców i materiałów. Jak wynika $\mathrm{z}$ danych ministerstw, na koniec I półrocza dotacje na założenie własnej firmy dostało prawie 30 tys. osób, z tego tylko 313 niepełnosprawnych, 1,7 tys. osób 
w wieku 50-64 lata i 4,5 tys. osób młodych. Dominują mieszkańcy obszarów wiejskich, do których trafiło aż 11,3 tys. dotacji.

\section{Programy na rozpoczęcie własnej działalności gospodarczej zawarte zostały w ramach} 16 Regionalnych Programów Operacyjnych i są dostępne w poszczególnych województwach w ramach różnych działań.

W ramach programów operacyjnych przewidziano środki pieniężne na uruchomienie i rozwój mikroprzedsiębiorstw, niemniej każde województwo opracowało własny dokument i w związku z tym, zarówno programy, jak i ich budżety są zróżnicowane (co ukazano w tabeli 2).

Tab. 2. Wybrane działania z RPO skierowane na założenie działalności gospodarczej w poszczególnych województwach na lata 2007-2013

\begin{tabular}{|c|c|c|c|}
\hline Województwo & Nazwa i nr działania & $\begin{array}{c}\text { Budżet } \\
\text { (mln euro) }\end{array}$ & $\begin{array}{c}\text { Poziom refundacji } \\
\text { kosztów }(\%)\end{array}$ \\
\hline Dolnośląskie & 1.1. Inwestycje dla przedsiębiorstw & 247 & 60 \\
\hline $\begin{array}{l}\text { Kujawsko- } \\
\text {-pomorskie }\end{array}$ & $\begin{array}{l}\text { 5.2.1. Wsparcie inwestycji mikroprzedsię- } \\
\text { biorstw }\end{array}$ & 17 & 70 \\
\hline Lubelskie & $\begin{array}{l}\text { Dotacje dla nowych mikroprzedsiębiorstw } \\
\text { Dotacje inwestycyjne dla mikroprzedsię- } \\
\text { biorstw }\end{array}$ & $\begin{array}{l}45 \\
136\end{array}$ & 70 \\
\hline Lubuskie & 2.1. Mikroprzedsiębiorstwa & 48 & 70 \\
\hline Łódzkie & $\begin{array}{l}\text { 3.2. Podnoszenie innowacyjności i konku- } \\
\text { rencyjności przedsiębiorstw }\end{array}$ & 173 & 70 \\
\hline Małopolskie & $\begin{array}{l}\text { 2.1. Rozwój i podniesienie konkurencyj- } \\
\text { ności przedsiębiorstw }\end{array}$ & 35 & 70 \\
\hline Mazowieckie & 1.5. Rozwój przedsiębiorczości & 473 & $60^{*}$ \\
\hline Opolskie & $\begin{array}{l}\text { 1.1.2. Inwestycje w mikroprzedsiębior- } \\
\text { stwach }\end{array}$ & 79 & 70 \\
\hline Podkarpackie & $\begin{array}{l}\text { 1.1. Wsparcie kapitałowe przedsiębior- } \\
\text { czości }\end{array}$ & 203 & 70 \\
\hline Podlaskie & $\begin{array}{l}\text { Wsparcie inwestycyjne przedsiębiorstw } \\
\text { 1.4.1. Mikroprzedsiębiorstwa }\end{array}$ & 90 & 70 \\
\hline Pomorskie & $\begin{array}{l}\text { 1.1. Mikro-, małe i średnie przedsiębior- } \\
\text { stwa }\end{array}$ & 104 & 60 \\
\hline Śląskie & 1.2.1. Mikroprzedsiębiorstwa & 77 & 60 \\
\hline Świętokrzyskie & $\begin{array}{l}\text { 1.1. Bezpośrednie wsparcie sektora mi- } \\
\text { kro-, małych i średnich przedsiębiorstw }\end{array}$ & 173 & 70 \\
\hline $\begin{array}{l}\text { Warmińsko- } \\
\text {-mazurskie }\end{array}$ & $\begin{array}{l}\text { 1.1.7. Dotacje inwestycyjne dla mikro- } \\
\text { i MŚP na innowacje i nowe technologie } \\
\text { 1.1.9. Inne inwestycje w przedsiębiorstwa }\end{array}$ & $\begin{array}{l}19 \\
74\end{array}$ & 70 \\
\hline Wielkopolskie & 1.1. Rozwój mikroprzedsiębiorstw & 26 & 60 \\
\hline $\begin{array}{l}\text { Zachodnio- } \\
\text { pomorskie }\end{array}$ & $\begin{array}{l}\text { 1.1.1. Bezpośrednie inwestycje } \\
\text { w mikroprzedsiębiorstwa }\end{array}$ & 77 & 60 \\
\hline
\end{tabular}

* miasto Warszawa - refundacja 50\% kosztów kwalifikowanych

Źródło: opracowanie własne. 


\section{Ostatnią z form pomocy unijnej jest Program Rozwoju Obszarów Wiejskich (PROW), który udziela wsparcia przy zakładaniu przedsiębiorstw na obszarach wiejskich.}

Biorąc pod uwagę fakt, że ponad 56\% ludności 27 państw członkowskich Unii Europejskiej (UE) mieszka na obszarach wiejskich, które stanowią 91\% jej terytorium, rozwój tych obszarów jest niezwykle ważną dziedziną polityki unijnej. Stąd UE przywiązuje dużą wagę do rozwoju tychże obszarów.

Program Rozwoju Obszarów Wiejskich na lata 2007-2013 jest instrumentem realizacji polityki Unii Europejskiej w zakresie rozwoju obszarów wiejskich (ROW). Program może odnosić się do terytorium całego kraju (tak jak to ma miejsce w Polsce) lub też przyjmowanych jest kilka różnych programów dla poszczególnych regionów jednolitych pod względem problemów ekonomicznych, społecznych oraz środowiskowych. Założenia i zakres PROW na lata 2007-2013 są efektem, zgodnie z którym nastąpi połączenie instrumentów finansowych rozwoju obszarów wiejskich, w obecnej perspektywie realizowanych w dwóch programach - PROW i SOP Rolnictwo i finansowanych z odrębnych źródeł, tj. funduszy strukturalnych oraz środków przeznaczonych na Wspólną Politykę Rolną. Efektem ujęcia rozwoju obszaró w wiejskich w jednolite ramy finansowe jest utworzenie Europejskiego Funduszu Rolnego na Rzecz Rozwoju Obszarów Wiejskich. W ramach Funduszu w okresie 2007-2013 dla krajów UE dostępne będzie 88,75 mld euro (w cenach z 2004 r.). W zakresie wsparcia przy zakładaniu przedsiębiorstw na obszarach wiejskich znaczącą rolę odgrywa Oś 3: Jakość życia na obszarach wiejskich i różnicowanie gospodarki wiejskiej, a w szczególności działanie 3.2. Tworzenie i rozwój mikroprzedsiębiorstw (7).

Instrumenty dostępne w ramach Osi 3 uzupełniają priorytety zdefiniowane w ramach pierwszych dwóch osi i w sposób synergiczny mogą pozytywnie oddziaływać na mieszkańców obszarów wiejskich. Pobudzanie działalności gospodarczej na obszarach wiejskich będzie pośrednio wpływać także na możliwość koncentracji produkcji rolniczej i przejścia ludności związanej z rolnictwem do pracy w innych sektorach gospodarki, a co za tym idzie - tworzyć warunki dla przekształceń wewnątrz sektora rolnego, w tym zwłaszcza redukcji bezrobocia ukrytego, powiększania areału gospodarstw rolnych, ich modernizacji, poprawy konkurencyjności i ukierunkowania rynkowego produkcji. W Polsce te działania stanowią ogromną szansę dla mieszkańców obszarów wiejskich, przede wszystkim ze względu na duże zasoby ludzkie wysoki poziom bezrobocia. Do najważniejszych zadań należy zwiększanie wartości dodanej do produktów, np. poprzez konfekcjonowanie, stymulowanie rynku produktów lokalnych i regionalnych, turystyki, handlu, doradztwa i usług.

W zakresie działania 3.2. Tworzenie i rozwój mikroprzedsiębiorstw z góry wskazano rodzaje działalności, które uprawniają do ubiegania się o pomoc unijną, a do których należą: usługi dla gospodarstw rolnych lub leśnictwa, usługi dla ludności, sprzedaż hurtowa i detaliczna, rzemiosło lub rękodzielnictwo, roboty i usługi budowlane oraz instalacyjne, usługi turystyczne oraz związane ze sportem, rekreacją i wypoczynkiem, usługi transportowe, usługi komunalne, przetwórstwo produktów rolnych lub jadalnych produktów leśnych, magazynowanie lub przechowywanie towarów, wytwarzanie produktów energetycznych z biomasy oraz usługi z zakresu rachunkowości, doradztwa lub usług informatycznych.

Beneficjentem pomocy moga być:

- osoby fizyczne lub prawne oraz jednostki organizacyjne nieposiadające osobowości prawnej, które prowadzą (podejmują) działalność jako mikroprzedsiębiorstwo zatrudniające poniżej 10 osób i mające obrót nieprzekraczający równowartości w zł 2 mln euro;

- osoby, które uzasadnią w opracowanym i przedłożonym biznesplanie ekonomiczną celowość podejmowanego przedsięwzięcia, zatrudnią minimum 1 osobę przy dofinansowaniu 
do 100 tys. PLN, powyżej 2 i mniej niż 5 przy dofinansowaniu do 200 tys. PLN oraz utworzą co najmniej 5 miejsc pracy (w przeliczeniu na pełne etaty średnioroczne) przy dofinansowaniu do 300 tys. PLN, zaś siedziba, oddział lub miejsce zamieszkania przedsiębiorcy oraz, w przypadku operacji związanych z nieruchomością, miejsce położenia nieruchomości, gdzie będzie prowadzona działalność gospodarcza znajdują się na ternie gminy: wiejskiej, wiejsko-miejskiej lub miejskiej o liczbie mieszkańców poniżej 5 tys. osób.

Pomoc unijna w tymże działaniu ma formę zwrotu części kosztów kwalifikowanych przedsięwzięcia gospodarczego. Wysokość pomocy przyznanej na realizację operacji waha się od 100 tys. PLN do 300000 tys. PLN, w zależności od utworzonych miejsc pracy, przy czym poziom pomocy finansowej wynosi maksymalnie 50\% kosztów kwalifikowanych operacji.

\section{Bariery w wykorzystaniu funduszy unijnych}

Możliwości uzyskania wsparcia finansowego dla osób, które myślą o założeniu własnej firmy z funduszy unijnych w ramach Europejskiego Funduszu Społecznego, Europejskiego Funduszu Rozwoju Regionalnego czy też Europejskiego Funduszu Rolniczego na rzecz Rozwoju Obszarów Wiejskich ze wszech miar należy ocenić pozytywnie, tym bardziej, że w okresie programowania 2007-2013 znacznie wzrosły budżety poszczególnych programów w tym zakresie w porównaniu z okresem 2004-2006.

Niemniej oprócz tych pozytywnych tendencji można również wskazać na ograniczenia w dostępie do funduszy unijnych, do których niewątpliwie można zaliczyć:

1. brak przejrzystych informacji odnośnie terminów i instytucji obsługujących dany program unijny oraz często skomplikowane wytyczne odnośnie poszczególnych programów - z reguły każdy z programów ma własne wytyczne, co powoduje, że przedsiębiorca musi zapoznać się z szeregiem wymogów dotyczących realizacji poszczególnych projektów;

2. możliwość wyczerpania puli środków znacznie szybciej niż przewiduje okres programowania, np.: eksperci rządowi oceniają, że jeżeli liczba wniosków w ramach PO KL będzie wzrastała tak szybko, jak dotychczas, to funduszy wystarczy tylko do 2011 r. (Czubkowska S., 2009, s. A1);

3. trudności w kwalifikacji kosztów na grupę kosztów kwalifikowanych uprawniających do refundacji inwestycji ze środków UE i kosztów niekwalifikowanych;

4. w wielu programach unijnych wymagany jest wkład własny, co powoduje, że często na skutek braku środków własnych część z przedsiębiorców nie może z nich skorzystać - rezygnuje już na etapie wstępnym z aplikacji o środki w ramach takich programów;

5. wymagania formalne odnośnie opracowania biznesplanu oraz wniosku o dotację unijną często stanowią dużą barierę, szczególnie w przypadku mikroprzedsiębiorstw lub osób rozpoczynających działalność gospodarczą po raz pierwszy (Tokarski M., 2009, s. 581-588);

6. fundusze unijne podlegają opodatkowaniu - tym samym kwota otrzymanej dotacji unijnej stanowi podstawę naliczenia podatku dochodowego;

7. skorzystanie ze środków unijnych nakłada na przedsiębiorcę konieczność prowadzenia działalności gospodarczej przez co najmniej 5 lat, co może być trudne do spełnienia w przypadku przedsięwzięć na niewielką skalę (Rękas M., 2009, s. 415).

\section{Zakończenie}

Polsce na lata 2007-2013 przyznano ponad 85 mld euro unijnej pomocy w ramach Europejskiego Funduszu Społecznego, Europejskiego Funduszu Rozwoju Regionalnego czy też Europejskiego Funduszu Rolniczego na rzecz Rozwoju Obszarów Wiejskich na realizację różnych programów, w tym również na rozpoczęcie działalności gospodarczej przez firmy 
sektora MŚP, którym wyjątkowo często brakuje kapitału w początkowej fazie rozwoju firmy. Możliwości uzyskania wsparcia finansowego dla osób, które myślą o założeniu własnej firmy z funduszy unijnych, ze wszech miar należy ocenić pozytywnie, tym bardziej, że w okresie programowania 2007-2013 znacznie wzrosły budżety poszczególnych programów w tym zakresie w porównaniu do okresu 2004-2006. Środki unijne mogą więc z pewnością stanowić szansę na rozpoczęcie działalności gospodarczej. Trudno dziś wyciagnąć jednoznaczne wnioski odnośnie realizacji założonych celów oraz efektywności wykorzystania zaplanowanej kwoty środków w ramach poszczególnych programów. Taką analizę będzie można przeprowadzić po zakończeniu okresu programowania - wskazując jednoznacznie na zaistniałe problemy oraz formułując wnioski odnośnie możliwości ich eliminacji w przyszłości. Niemniej zainteresowanie polskich przedsiębiorców możliwością absorpcji funduszy unijnych z roku na rok wzrasta, o czym może świadczyć możliwość wyczerpania puli środków znacznie szybciej, niż przewiduje to bieżący okres programowania.

\section{Literatura}

1. Naruszewicz S. (red.) 2005, Fundusze Strukturalne w Polityce Regionalnej, Wydawnictwo Politechniki Białostockiej, Białystok.

2. Jankowska A., Kierkowski T., Knopik R., 2004, Fundusze pomocowe dla Polski po akcesji-fundusze strukturalne i fundusz spójności, PARP, Warszawa.

3. Czubkowska S., 2009, 11 mld euro z Unii rozejdzie sie przed czasem, „Dziennik Gazeta Prawna”, nr 204 z 19.10.2009 r., Wyd. Infor, Warszawa.

4. Tokarski M., 2009, Najczęściej popetniane błędy w sporzqdzaniu biznesplanów przez mikro- $i$ mate przedsiębiorstwa [w:] Uwarunkowania rynkowe rozwoju mikro- $i$ malych przedsiębiorstw - Mikrofirma 2009, pod red. A. Bielawskiej, Uniwersytet Szczeciński, Szczecin.

5. Rękas M., 2009, Fundusze unijne szansq na rozpoczęcie działalności gospodarczej [w:] Uwarunkowania rynkowe rozwoju mikro i matych przedsiębiorstw - Mikrofirma 2009, pod red. A. Bielawskiej, Uniwersytet Szczeciński, Szczecin.

6. http://www.wup.torun.pl/

7. http://prow.rolnicy.com/

\section{UE Funds as a Chance for New Micro-, Small and Medium-sized Enterprises Start-up}

Poland has been awarded nearly 85 billion euros for the new financing period, 2007-2013, in order to implement various programs aimed at reaching Europan standards.

The aim of this chapter is to show a panorama of the UE funds available to Polish entrepreneurs from SME's for the purpose of starting a business in the 2007-2013 period, as well to point out the barriers hindering their access to the EU resources. 